\title{
Adherence of non-fimbriate entero-invasive Escherichia coli 0124 to guinea pig intestinal tract in vitro and in vivo
}

\section{S. ASHKENAZI}

\author{
Department of Pediatrics A, Beilinson Medical Center, Petah Tigva (49 100) and Tel Aviv University \\ Sackler School of Medicine, Israel
}

\begin{abstract}
Summary. The adherence properties of non-fimbriate entero-invasive Escherichia coli O124 in the guinea pig intestinal tract were studied. Quantitative in-vitro determinations were done by incubating radiolabelled bacteria with suspensions of viable intestinal cells released by treating loops of the guinea pig intestine with solutions containing EDTA, dithiothreitol and citrate. Non-bound bacteria were separated from the intestinal cells on a Percoll gradient. Only cells released from the colon, especially from its transverse and descending regions, avidly adhered to $E$. coli $\mathrm{O} 124$ (68-79 bacteria/cell), whereas the attachment to ileal cells was negligible. The adherence process was $\mathrm{Ca}^{++}$and temperature-dependent, had an optimal $p \mathrm{H}$ of 6.2 and was inhibited by fucose, glucose or mannose. Several pretreatment studies of the bacteria or the colonic cells showed that the adherence was mediated by a carbohydrate-binding protein (adhesin or lectin) on the colonic cells and not on the bacterial surface. Results of studies of in-vitro adherence to intestinal loops and to intact intestinal surfaces correlated well with the in-vitro findings. These results indicate that the adherence of entero-invasive $E$. coli 0124 to the gut is similar to the attachment of Shigella flexneri and is quite different from that of enterotoxigenic $E$. coli.
\end{abstract}

\section{Introduction}

Escherichia coli is a major component of the normal flora of the intestinal tract (Mackowiak, 1982), but is also an important cause of diarrhoeal diseases (Drachman, 1974). The enteric diseases caused by $E$. coli can be classified into at least two types. Some $E$. coli strains (enterotoxigenic $E$. coli, ETEC) colonise the small intestine, elaborate an enterotoxin and produce a watery diarrhoea in infants and adults; this type is especially common in developing countries and in travellers from developed countries (Guerrant et al., 1975; Sack, 1980). The ability to secrete enterotoxin (either heat-stable or cholera-like heat-labile) is usually plasmidmediated (Back et al., 1980). Other E. coli strains are entero-invasive and cause a dysentery-like syndrome with bloody stool, tenesmus and fever (Guerrant et al., 1975; Cantey et al., 1977).

The adherence of bacteria to epithelial surfaces has been found to be an essential requirement for colonisation (Hartley et al., 1979) and virulence (Cheney et al., 1980; Boedeker, 1982). Attachment to the intestinal epithelium enables the micro-

Received 9 Jan. 1985: revised version accepted 21 Apr. 1985. organisms to resist peristaltic clearing mechanisms and colonise the intestine, sometimes with subsequent enterotoxin production or tissue invasion.

The adherence properties of ETEC have been extensively investigated and depend on bacterial surface appendages such as fimbriae. Several surface antigens (K88 and K99) have been isolated from animal ETEC strains (Isaacson, 1977; Mooi and deGraaf, 1979) and from human strains, in which they are called colonisation-factor antigens (Evans and Evans, 1978; Deneke et al., 1979). Some of them have been purified and well characterised (Isaacson, 1977; Evans et al., 1979). Adherence of $E$. coli to the mucosa of the small intestine without evidence of enterotoxin production or invasion has been described as associated with protracted diarrhoea in infants (Ulshen and Rollo, 1980; Rothbaum et al., 1982). On the other hand, the adherence properties of entero-invasive strains of $E$. coli, whose virulence is not clearly plasmid-mediated (Nandadasa et al., 1981; Silva et al., 1982), has not yet been clarified.

A system for studying the adherence of bacteria to the guinea pig intestinal tract has been described recently (Izhar et al., 1982; Ashkenazi and Mirel- 
man, 1984). In the present study the adherent properties of a non-fimbriate entero-invasive $E$. coli strain were examined and compared with those of a non-invasive strain of $E$. coli and a strain of Shigella flexneri.

\section{Materials and methods}

Adherence of $E$. coli to guinea pig intestinal tract was quantitatively determined with radiolabelled bacteria as follows.

\section{Bacteria}

A clinical isolate of $E$. coli $\mathrm{O} 124$ was obtained from $\mathrm{Dr}$ G. Altman, Department of Microbiology, Tel Hashomer Hospital, Israel, and of E. coli O128:H4 was obtained from Dr N. Gerber, Bar Ilan University, Israel. E. coli strains were grown in peptone (Difco) $1 \%$, yeast extract $0.5 \%$ and $\mathrm{NaCl} 0.5 \%$. S. flexneri was grown in Luria broth, supplemented with $5 \mathrm{~mm} \mathrm{CaCl} 2$ and glucose $0.2 \%$. The invasiveness of $E$. coli $\mathrm{O} 124$ was repeatedly tested by the guinea pig eye inoculation technique (Sereney, 1957).

\section{Preparation of radiolabelled bacteria}

Sixteen hours before each experiment, bacteria were transferred by a sterile wire loop from stock agar slants to freshly prepared media, with the addition of $0.2 \mathrm{ml} \mathrm{D}$ $\left({ }^{14} \mathrm{C}\right)$-glucose $(239 \mathrm{mCi} / \mathrm{mmol}, 0 \cdot 1 \mathrm{uCi} / \mathrm{ml}$; The Radiochemical Centre, Amersham), and incubated at $37^{\circ} \mathrm{C}$. The bacteria were harvested by centrifugation at $900 \mathrm{~g}$. for 10 min and washed three times by suspension in saline and re-centrifugation. The sedimented bacteria were resuspended in isotonic saline and their concentration adjusted photometrically to give a suspension of $2 \times 10^{9}$ bacteria/ $\mathrm{ml}$. The radioactivity of the labelled bacteria was determined by counts in a Tricarb liquid scintillation spectrometer (model 3255, Packard Instrument Co., USA) with $10 \mathrm{ml}$ of Triton 100-Toluene scintillation fluid. The specific radioactivity obtained was $c .10^{6}$ counts $/ \mathrm{min} / 10^{9}$ bacteria. Precipitation in 5\% trichloroacetic acid showed that $>90 \%$ of the radiolabelled precursor was incorporated into macromolecular components of the bacteria.

\section{Preparation of intestinal epithelial cells}

A suspension of intestinal cells was obtained as described previously (Izhar et al., 1982; Ashkenazi and Mirelman, 1984). The technique of Weiser (1973) was used and sections of the intestine were treated with solutions containing EDTA, citrate buffer and dithiothreitol. The viability of the intestinal cells was monitored by trypan blue exclusion.

\section{Assay for bacterial adherence to epithelial cells}

A suspension of epithelial cells ( $\left.200 \mu \mathrm{l} ; 5 \times 10^{6} \mathrm{cells} / \mathrm{ml}\right)$ obtained from different regions of the intestinal tract was incubated with radiolabelled bacteria $\left(100 \mu \mathrm{l} ; 2 \times 10^{9}\right.$ bacteria/ml; 200 bacteria/epithelial cell) at $37^{\circ} \mathrm{C}$ in a rotating rack at $16 \mathrm{rpm}$. After $45 \mathrm{~min}$ the interaction was terminated by adding $2.5 \mathrm{ml}$ of saline and centrifuging at $500 \mathrm{~g}$ for $5 \mathrm{~min}$ to sediment the epithelial cells; the supernate, containing mainly the nonadherent bacteria, was discarded. The separation of the epithelial cells from the remaining nonadherent bacteria was performed by discontinuous density-gradient centrifugation with Percoll (Pharmacia Fine Chemicals, Uppsala, Sweden) (Izhar et al., 1982; Ashkenazi and Mirelman, 1984). The layer of epithelial cells with the adherent bacteria was collected and counted for radioactivity.

\section{Assay for bacterial adherence to intact intestinal surface}

Sections of guinea pig intestine were obtained after washing the saline. They were opened by a longitudinal incision and placed on a flat plastic surface with the mucosa facing upwards. A cover containing three oval holes with a surface area of $0.38 \mathrm{~cm}^{2}$ was screwed on to the mucosal surface. The exposed portion of the mucosa was incubated with radiolabelled bacteria $\left(100 \mu \mathrm{l} ; 2 \times 10^{9}\right.$ bacteria/ml) (Izhar et al., 1982). The preparation was incubated at $37^{\circ} \mathrm{C}$ for $45 \mathrm{~min}$ in a humid chamber and the reaction was then terminated by washing the tissue three times with saline. The tissue was taken out of the instrument, the area of intestinal mucosa that had been exposed to the labelled bacteria was cut out and heated at $100^{\circ} \mathrm{C}$ for $15 \mathrm{~min}$ in a tube containing $1 \mathrm{ml}$ of $2 \%$ sodium dodecyl sulphate. The adherent radiolabelled bacteria were solubilised under these conditions (Braun, 1975) and their released radioactivity was determined as described previously.

\section{Assay for in-vitro bacterial adherence to intestinal loops}

Each guinea pig was anaesthetised and the peritoneal cavity opened. Loops $(2 \mathrm{~cm}$ long) were created in the intestine by surgical sutures. A suspension of radiolabelled bacteria $\left(200 \mu \mathrm{l}, 10^{9}\right.$ bacteria/ml) was carefully introduced into each loop with a 26-gauge needle; the loops were then replaced in the peritoneal cavity and the abdomen covered for $45 \mathrm{~min}$. Thereafter, each loop was cut from the intestine, washed with saline and then the opened intestine was spread and scraped gently with a glass slide. The tissue was suspended in $5 \mathrm{ml}$ of saline, centrifuged at $500 \mathrm{~g}$ for $5 \mathrm{~min}$ and the non-adherent bacteria were separated from the intestinal mucosa on the Percoll gradient, as decribed above. The radioactivity of the radiolabelled bacteria that adhered to the mucosa was determined. A tenth part of the suspension of mucosal scrapings was taken for protein determination (Lowry et al., 1951) and the results were expressed as adherence per $\mathrm{g}$ of protein. 


\section{Statistical methods}

All the experiments were done in triplicate. Results are reported mean \pm standard error of the mean $(M \pm S E M)$.

\section{Scanning electron microscopy}

After the assay for bacterial adherence, the intestinal cells or intestinal mucosa were washed in saline, fixed with glutaraldehyde $2 \%$ for $1 \mathrm{~h}$, and washed with $0 \cdot 1 \mathrm{~m}$ sodium cacodylate buffer at $p \mathbf{H} 7 \cdot 2$. They were then incubated with osmium tetraoxide $1 \%$ for $30 \mathrm{~min}$ and dried to a critical point. The tissue was fixed to planchets, coated with gold and examined with a JSM-35c scanning electronmicroscope (Jeol, Japan).

\section{Results}

The invasiveness of $E$. coli $\mathrm{O} 124$ was repeatedly confirmed by producing keratoconjunctivitis in guinea pigs. Electronmicrographs of negatively stained cells revealed that the bacteria did not have any cell surface appendages, and they did not agglutinate mannan-containing yeast cells (Mirelman et al., 1980) or erythrocytes. E. coli $\mathrm{O} 124: \mathrm{H} 4$, whose adherent properties were compared with those of $E$. coli $\mathrm{O} 124$, was not invasive, possessed type-I fimbriae (Gaastra and deGraaf, 1982) and agglutinated yeast cells and guinea pig, but not human, erythrocytes.

\section{Adherence to intestinal cells}

Quantitative examination of the adherence of the bacteria to intestinal cells from various regions of the intestine (table I) showed that E. coli O124 adhered well to colonic cells, mainly those released from its transverse and descending regions (68-79 bacteria/cell). Its adherence to ilial cells was negligible $(<2$ bacteria/cell). E. coli $\mathrm{O} 128$ showed less

Table I. Adherence of E. coli O124 and E. coli O124 to guinea pig intestinal cells released from various regions of the intestine*

\begin{tabular}{|c|c|c|}
\hline \multirow{2}{*}{$\begin{array}{l}\text { Region of the } \\
\text { intestine }\end{array}$} & \multicolumn{2}{|c|}{$\begin{array}{l}\text { Number of adherent bacteria/cell } \\
\text { in tests with }\end{array}$} \\
\hline & E. coli $\mathrm{O} 124$ & E. coli 0128 \\
\hline Small intestine & $2 \pm 1$ & $19 \pm 3$ \\
\hline Ascending colon & $18 \pm 6$ & $14 \pm 3$ \\
\hline $\begin{array}{l}\text { Transverse and } \\
\text { descending colon }\end{array}$ & $73 \pm 9$ & $42 \pm 6$ \\
\hline
\end{tabular}

* Radiolabelled bacteria $\left(2 \times 10^{*}\right)$ were incubated with the intestinal cells $\left(10^{6}\right)$ at $37^{\circ} \mathrm{C}$ for $45 \mathrm{~min}$. affinity for colonic cells, but adhered well to cells released from the small intestine (17-20 bacteria/ cell).

The adherence of E. coli $\mathrm{O} 124$ to colonic cells was temperature dependent, required $\mathrm{Ca}^{++}$ions (fig. 1), and the optimal $p \mathrm{H}$ was $6 \cdot 2$. Significant inhibition of the attachment (c. 80\%) was achieved by $50 \mathrm{~mm}$ fucose and $100 \mathrm{~mm}$ glucose (table II). Mannose (100 $\mathrm{mM}$ ) caused only c. $50 \%$ inhibition and other

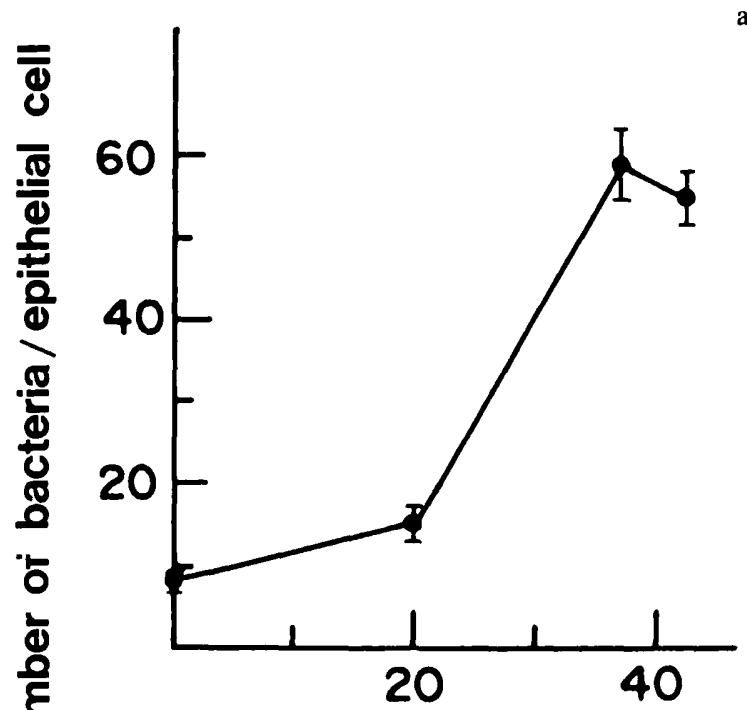

\section{Incubation temperature ${ }^{\circ} \mathrm{C}$}

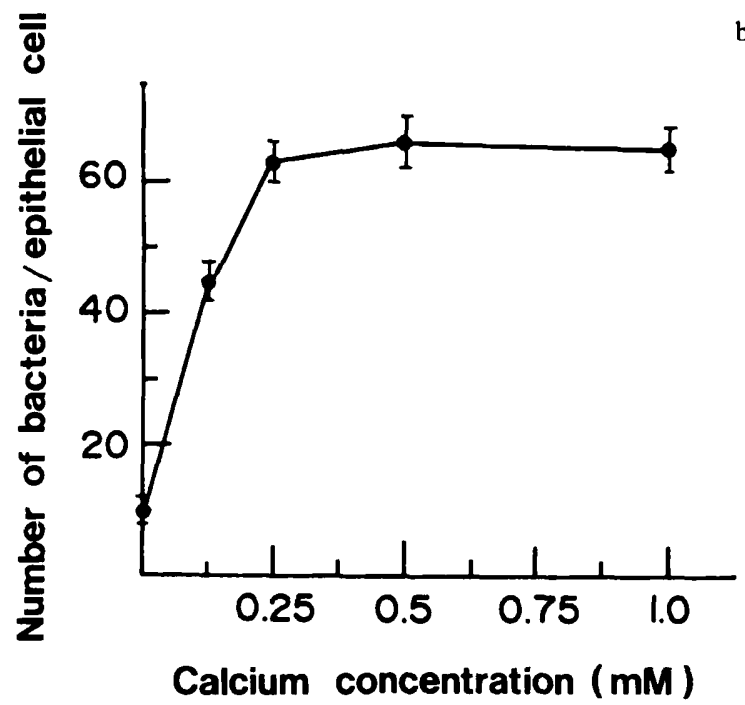

Figs $1 \mathrm{a}$ and 1b. The effect of temperature of incubation (fig. la) and $\mathrm{Ca}^{++}$concentration (fig. $1 \mathrm{~b}$ ) on the adherence of $E$. coli O124 to colonic cells. Radiolabelled bacteria ( 200 bacteria/cell) were incubated for $45 \mathrm{~min}$ with viable epithelial cells. 
carbohydrates had no inhibitory effect. Lipopolysaccharide (LPS) of E. coli O124, prepared by the phenol-water extraction method (Westphal and Jann, 1965), was also a potent inhibitor of the adherence: $79 \%$ inhibition was achieved at an LPS concentration of $1 \mathrm{mg} / \mathrm{ml}$ (table II).

The effect of several pretreatments on the adherence process was examined. Pretreatment of the colonic cells by glutaraldehyde fixation, proteolytic digestion or heat inactivation (Izhar et al., 1982) completely abolished their adhesiveness for the test bacteria. Preincubation of the colonic cells with fucose $10 \mathrm{mg} / \mathrm{ml}$ at $37^{\circ} \mathrm{C}$ for $45 \mathrm{~min}$, followed by washing, also inhibited $>90 \%$ of the attachment. On the other hand, similar pretreatments of the bacteria did not affect their subsequent adherence to the colonic cells.

Preincubation of the colonic cells with $2 \times 10^{8}$ unlabelled $E$. coli $\mathrm{O} 128$ for $45 \mathrm{~min}$ competitively inhibited $(41 \%)$ the subsequent adherence of radiolabelled E. coli $\mathrm{O} 124$ (fig. 2). E. coli O124 also inhibited the adherence of radiolabelled $E$. coli O128 in a converse experiment, indicating that the attachment of these bacteria to colonic cells is probably by the same mechanism.

The adherence of $E$. coli $\mathrm{O} 128$ to ileal cells had different characteristics. Mannose was the only carbohydrate which caused $>50 \%$ inhibition of the attachment whereas others, including fucose and glucose, had no inhibitory effect. In contrast to the findings with the colonic cells, the various pretreatments described above significantly inhibited the adherence process $(>90 \%)$ only when performed on the bacteria; pretreatments of the ileal cells had no inhibitory effect. These results are summarised in table III.

Table II. Inhibition of the adherence of E. coli $\mathrm{O} 124$ to guinea pig colonic cells

\begin{tabular}{lc}
\hline \multicolumn{1}{c}{ Compound tested } & Percentage adherence* \\
\hline Fucose $(10 \mathrm{mg} / \mathrm{ml})$ & $21 \pm 3$ \\
Glucose $(10 \mathrm{mg} / \mathrm{ml})$ & $27 \pm 6$ \\
Mannose $(10 \mathrm{mg} / \mathrm{ml})$ & $54 \pm 3$ \\
Rhamnose $(10 \mathrm{mg} / \mathrm{ml})$ & $97 \pm 10$ \\
Lactose $(10 \mathrm{mg} / \mathrm{ml})$ & $98 \pm 11$ \\
Lipopolysaccharide $\dagger(1 \mathrm{mg} / \mathrm{ml})$ & $21 \pm 1$
\end{tabular}

\footnotetext{
* Results represent $\bar{M} \pm$ SEM of ten experiments for fucose, glucose and mannose and three experiments for the other compounds. Adherence is expressed as a percentage of that observed in control tests without the relevant test compound.

+ See Methods.
}

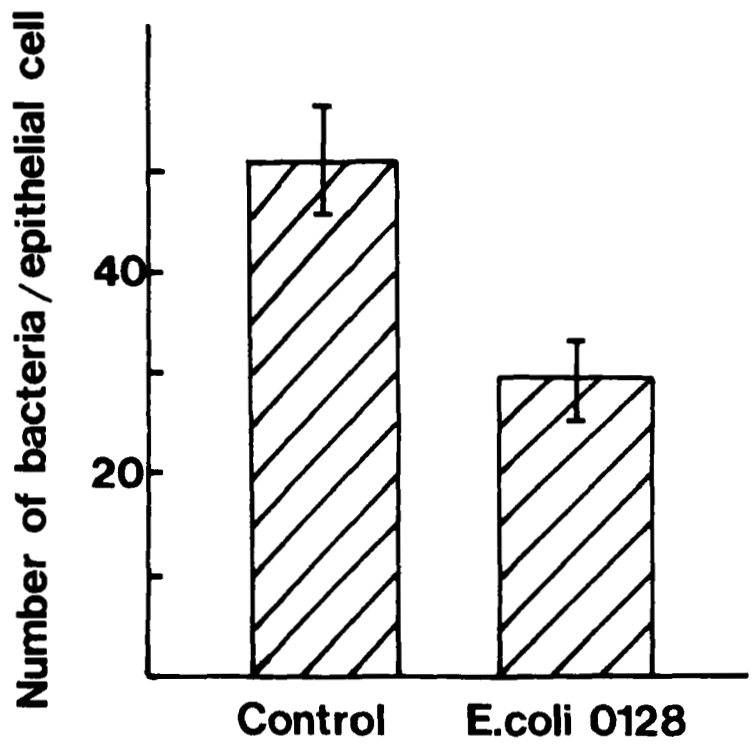

Fig. 2. Inhibition of the adherence of radiolabelled $E$. coli $\mathrm{O} 124$ to guinea pig colonic cells by preincubation with unlabelled $E$. coli $\mathrm{O} 128$.

Bacterial adherence to intestinal surfaces and to intestinal loops in-vivo

The purpose of these experiments was to determine any correlation between the bacterial adherence to suspension of epithelial cells in vitro and the adherence to intestinal surfaces and intestinal loops in vivo. E. coli $\mathrm{O} 124$ avidly adhered to intact colonic surfaces and to colonic loops in a living animal. Quantitative determinations with radiolabelled bacteria showed that the adherence of $E$. coli $\mathrm{O} 128$ to the colonic surface was $1.63 \times 10^{7} \pm 2 \times 10^{6}$ bacteria $/ \mathrm{cm}^{2}$. The number of colonic cells released from the colon was $2.52 \times 10^{5} \pm 4 \times 10^{4}$ cells $/ \mathrm{cm}^{2}$; adherence was therefore at a rate of 63 bacteria/cell, similar to the findings in vitro. The attachment to the colon in vivo was also $\mathrm{Ca}^{++}$dependent, and was inhibited by fucose and glucose (fig. 3 ). The adherence of $E$. coli $\mathrm{O} 124$ to the ileum showed the same characteristics as adherence in vitro to ileal cells (data not shown).

Scanning electronmicrographs (fig. 4) showed the marked adherence of $E$. coli $\mathrm{O} 124$ to colonic cells. In addition, the bacteria under investigation attached well to the colonic surface, including crypt areas. We found no histological evidence of phagocytosis of the bacteria or of bacteria inside the cells under our experimental conditions.

\section{Discussion}

The present results clearly indicate that the 
Table III. Comparison of the adherence properties of E. coli $\mathrm{O} 124$ and $E$. coli $\mathrm{O} 128$ to guinea pig intestinal tract

\begin{tabular}{|c|c|c|}
\hline Item & E. coli $\mathrm{O} 124$ & E. coli $\mathrm{O} 128$ \\
\hline $\begin{array}{l}\text { Region of } \\
\text { adherence }\end{array}$ & $\begin{array}{l}\text { Colon only (especially } \\
\text { transverse and descending) }\end{array}$ & $\begin{array}{l}\text { Small and large } \\
\text { intestine }\end{array}$ \\
\hline $\begin{array}{l}\text { Main inhibitory } \\
\text { carbohydrate(s) }\end{array}$ & Fucose, glucose & Mannose \\
\hline Dependence on $\mathrm{Ca}^{++}$ions & Yes & Yes \\
\hline Dependence on $p \mathrm{H}$ & Yes (optimum 6·2) & Yes (optimum 6.2) \\
\hline $\begin{array}{l}\text { Pretreatment of } \\
\text { intestinal cells }\end{array}$ & $\begin{array}{l}\text { Inhibited adherence } \\
(>90 \%)\end{array}$ & No effect \\
\hline Pretreatment of bacteria & No effect & $\begin{array}{l}\text { Inhibited adherence } \\
(>90 \%)\end{array}$ \\
\hline Location of the adhesin & On intestinal mucosa & On bacterial surface \\
\hline
\end{tabular}
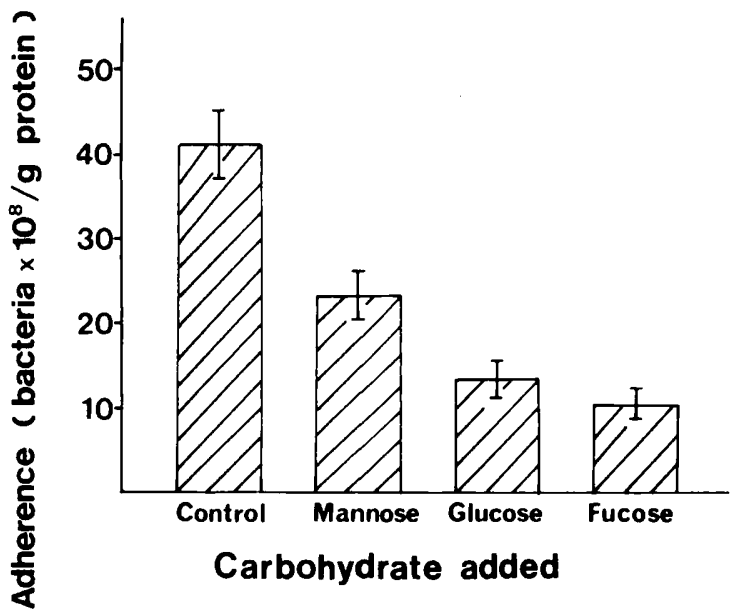

Fig. 3. Adherence of E. coli $\mathrm{O} 124$ to colonic loops in a living animal after incubation for $45 \mathrm{~min}$. The carbohydrates were added together with the radiolabelled bacteria at a final concentration of $10 \mathrm{mg} / \mathrm{ml}$.

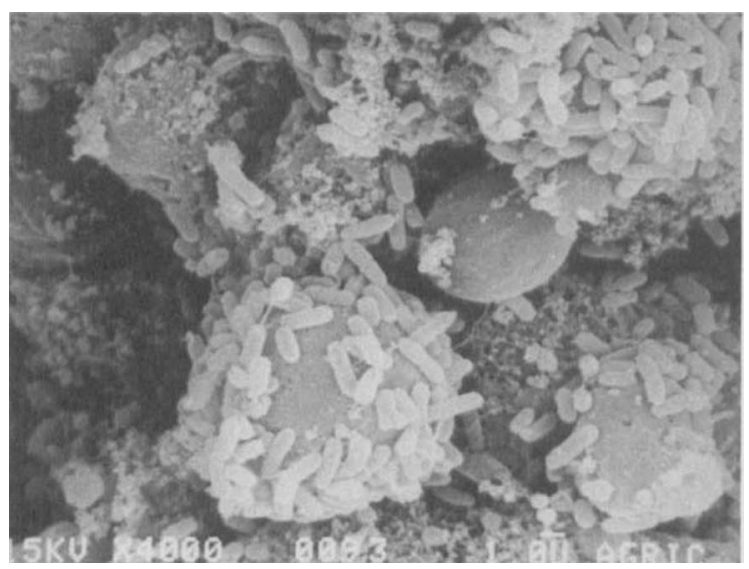

Fig. 4. Scanning electron micrographs of adherence of $E$. coli 0124 to guinea pig colonic cells $(\times 4000)$. adherence of the non-fimbriate entero-invasive $E$. coli strain to guinea pig intestinal tract differs from that of the non-invasive ETEC strains studied previously (table III).

The attachment of several non-invasive strains of $E$. coli was shown in this study and in several previous works (Deneke et al., 1979; Gaastra and deGraaf, 1982), to depend on bacterial proteins associated with cell-surface appendages such as pili or fimbriae. These proteins possess specific properties for recognising carbohydrates and are named lectins or adhesins. They are bound to specific receptors, usually carbohydrate moieties, on the intestinal surface. The $E$. coli strain examined in this study bound well to the small intestine, and our findings suggest that a mannose receptor is involved, as has been found in other studies.

On the other hand, the entero-invasive $E$. coli O124 attached only to the colon, mainly its transverse and descending portions. The adherence process was inhibited most effectively by fucose and glucose, which did not affect the attachment of ETEC to the small intestine. Moreover, results of pretreatment studies indicated that the adherence depended on a protein on the host cells of the intestinal surface and not on the bacteria. This protein mediated the attachment of bacteria to the colon by recognising carbohydrate receptors on the bacterial surface. This explains the inhibitory effect of fucose and glucose, as well as the LPS of the bacteria. This adhesin is a carbohydrate-binding protein and is secreted with the intestinal mucus, from which it has been purified and partially characterised by affinity chromatography and sodiumdodecyl-sulphate (SDS) polyacrylamide gel electrophoresis (Mirelman et al., 1985).

The two different patterns of adherence of pathogenic $E$. coli to the gut produce two separate 
intestinal syndromes. The ETEC cause an acute watery diarrhoea by colonizing the small intestine and producing an enterotoxin. The invasive $E$. coli usually cause a dysentery-like disease, characterised by high fever, bloody diarrhoea and abdominal cramps. The pathogenesis of the diarrhoea produced by these strains is invasion of the intestinal epithelium, predominantly of the colon. Adherence to the intestine is probably a prerequisite for subsequent enterotoxin action or invasion.

Recently a third mechanism for $E$. coli-associated diarrhoea has been suggested (Ulshen and Rollo, 1980; Rothbaum et al., 1982); this postulates bacterial adherence to the mucosa of the small intestine with disruption of the brush border, but without either enterotoxin production or tissue invasion.

\section{REFERENCES}

Ashkenazi S, Mirelman D 1984 The effect of postnatal age on the adherence of Shigella flexneri, Escherichia coli 0124 and Escherichia coli O128 to guinea pig intestinal cells. Pediatric Research 18:1366-1371.

Back E, Möllby R, Kaijser B, Stintzing G, Wadström T, Habte D 1980 Enterotoxigenic Escherichia coli and other gramnegative bacteria of infantile diarrhea: surface antigens, hemagglutinins, colonization factor antigen and loss of enterotoxigenicity. Journal of Infectious Diseases 142:318327.

Boedeker E C 1982 Enterocyte adherence of Escherichia coli: its relation to diarrheal disease. Gastroenterology 83:489-492.

Braun V 1975 Covalent lipoprotein from the outer membrane of Escherichia coli. Biochimia et Biophysica Acta 415:335-377.

Cantey J R, O'Hanley P D, Blake R K 1977 A rabbit model of diarrhea due to invasive Escherichia coli. Journal of Infectious Diseases 136:640-648.

Cheney C P, Schad P A, Formal S B, Boedeker E C 1980 Species specificity of in vitro Escherichia coli adherence to host intestinal cell membranes and its correlation with in vivo colonization and infectivity. Infection and Immunity 28:1019-1027.

Deneke C F, Thorne G M, Gorbach S L 1979 Attachment pili from enterotoxigenic Escherichia coli pathogenic for humans. Infection and Immunity 26:362-368.

Deneke C F, McGowan K, Thorne G M, Gorbach S L 1983 Attachment of enterotoxigenic Escherichia coli to human intestinal cells. Infection and Immunity 39:1 102-1106.

Drachman R H 1974 Acute infectious gastroenteritis. Pediatric Clinics of North America 21:711-737.

Evans D G, Evans D J 1978 New surface-associated heat-labile colonization factor antigen (CFA/II) produced by enterotoxigenic Escherichia coli of serogroups 06 and 08. Infection and Immunity 21:638-647.

Evans D G, Evans D J, Clegg S, Pauley J A 1979 Purification and characterization of the CFA/I antigen of enterotoxigenic Escherichia coli. Infection and Immunity 25:738-748.

Gaastra W, deGraaf F K 1982 Host-specific fimbrial adhesins of non-invasive enterotoxigenic Escherichia coli strains. Microbiological Review's 46:129-161.

Guerrant R L, Moore R A, Kirschenfeld P M, Sandle M A 1975
The adherent properties of the enteroinvasive strain of E. coli examined in this study are similar to those of S. flexneri described in earlier studies (Izhar et al., 1982), which may explain why the presentation in man is often similar. Williams et al. (1984) have found that non-fimbrial surface proteins from two other invasive strains of $E$. coli mediated adherence to erythrocytes and tissue culture cells.

Caution is needed in any extrapolation of results obtained in guinea pigs to humans. Similar experiments in man have obvious limitations. Deneke $e t$ al. (1983) have described a method of obtaining human intestinal cells from longstanding ileostomies, and by using this approach the adherence of bacteria to human intestinal cells is under investigation in our laboratory.

Role of toxigenic and invasive bacteria in acute diarrhea of childhood. New' England Journal of Medicine 293:567-573.

Hartley C L, Neumann C S, Richmond M H 1979 Adhesion of commensal bacteria to the large intestine wall in humans. Infection and Immunity 23:128-132.

Isaacson R E 1977 K99 surface antigen of Escherichia coli: purification and partial characterization. Infection and Immunity 15:272-279.

Izhar M, Nuchamowitz Y, Mirelman D 1982 Adherence of Shigella flexneri to guinea pig intestinal cells is mediated by a mucosal adhesin. Infection and Immunity 35:1110-1118.

Lowry O H, Rosebrough N J, Farr A L, Randall R J 1951 Protein measurements with the Folin phenol reagent. Journal of Biological Chemistry 193:265-275.

Mackowiak P A 1982 The normal microbial flora. New England Journal of Medicine 307:83 93.

Mirelman D, Altmann G. Eshdat Y 1980 Screening of bacterial isolates for mannose-specific lectin activity by agglutination of yeasts. Journal of Clinical Microbiology 11:328-331.

Mirelman D, Nuchamowitz Y, Izhar M Interactions between intestinal cells and shigellac. Journal of Cellular Biochemistry (in press).

Mooi F R, de Graaf F K 1979 Isolation and characterization of K88 antigens. FEMS Microbiology Letters 5:17-20.

Nandadasa H G, Sargent G F, Brown M G M, McNeish A S, Williams P H 1981 The role of plasmids in adherence of invasive Escherichia coli to mammalian cells. Journal of Infectious Diseases 143:286-290.

Rothbaum R, McAdams A J, Gianella R, Partin J C 1982 A clinicopathologic study of enterocyte-adherent Escherichia coli: a cause of protracted diarrhea in infants. Gastroentero$\log y$ 83:441-454.

Sack R B 1980 Enterotoxigenic Escherichia coli: identification and characterization. Journal of Infectious Diseases 142:279-286.

Sereney B 1957 Experimental keratoconjunctivitis Shigellosa. Acta Microbiologica Academiale Scientiorum Hungaricae 4:367-376.

Silva R M, Toledo M R F, Trabulsi L R 1982 Correlation of invasiveness with plasmid in enteroinvasive strains of Escherichia coli. Journal of Infectious Diseases 146:706.

Ulshen M H, Rollo J L 1980 Pathogenesis of Escherichia coli gastroenteritis in man-another mechanism. New England Journal of Medicine 302:99-101. 
Weiser M M 1973 Intestinal epithelial cell surface membrane glycoprotein synthesis. 1. An indicator of cellular differentiation. Journal of Biological Chemistry 248:2536-2541.

Westphal O, Jann K 1965 Bacterial lipopolysaccharides. Extraction with phenol-water and further applications of the procedure. In: Whistler R L (ed) Methods of carbohydrate chemistry, 5. Academic Press, New York, pp 83-91.
Williams P H, Knutton S, Brown M G M, Candy D C A, McNeish A S 1984 Characterization of nonfimbrial mannose-resistant protein hemagglutinins of two Escherichia coli strains isolated from infants with enteritis. Infection and Immunity 44:592-598. 